\title{
Impact of biochar on mungbean yield and yield components
}

\author{
Abdul Rab ${ }^{1}$, Muhammad Rabnawaz Khan ${ }^{1 *}$, Sami Ul Haq ${ }^{2}$, \\ Salman Zahid ${ }^{1}$, Muhammad Asim ${ }^{3}$, Muhammad Zahir Afridi ${ }^{2}$, \\ Muhammad Arif ${ }^{1}$ and Fazal Munsif ${ }^{2}$ \\ 1. Department of Agronomy, Faculty of Crop Production Sciences, University of Agriculture Peshawar, Pakistan \\ 2. Department of Agronomy, Faculty of Crop Production Sciences, AMK campus, University of Agriculture, \\ Peshawar, Pakistan \\ 3. Department of Agronomy, Faculty of Agriculture, University of Agriculture Faisalabad, Pakistan \\ *Corresponding author's email: rabnawazagri@gmail.com \\ Citation \\ Abdul Rab, Muhammad Rabnawaz Khan, Sami Ul Haq, Salman Zahid, Muhammad Asim, Muhammad \\ Zahir Afridi, Muhammad Arif and Fazal Munsif. Impact of biochar on mungbean yield and yield \\ components. Pure and Applied Biology. Vol. 5, Issue 3, pp632-640. \\ http://dx.doi.org/10.19045/bspab.2016.50082
}

\begin{tabular}{llll}
\hline \hline Received: 22/12/2015 & Revised: 09/05/2016 & Accepted: 16/05/2016 & Online First: 28/06/2016 \\
\hline
\end{tabular}

\section{Abstract}

In order to evaluate the sole impact of biochar on yield and yield components of mungbean crop, a pot experiment was conducted at Agronomy Research Farm, Agriculture University Peshawar, Pakistan during summer 2013. The experiment was laid out in completely randomized design having four repeats. The treatments were consisted of 5 levels of biochar $(25,50,75,100$ tons $\mathrm{ha}^{-1}$ ) along with control. Early flowering (36) and maturity (81) was recorded in biochar treated plots as compared to control. The biochar levels significantly improved pods plant ${ }^{-1}$ (23), pods length $(9.2 \mathrm{~cm})$, grains pod ${ }^{-1}(11), 100$ grains weight $(6.8 \mathrm{~g})$, biological yield $\left(28.3 \mathrm{~g} \mathrm{pot}^{-1}\right)$, grain yield $\left(4.2 \mathrm{~g} \mathrm{pot}^{-1}\right)$ and harvest index $(14.87 \%)$. While days to emergence of mungbean were nonsignificant. Hence it was concluded from the experiment that the application of biochar at the rate of 25 tons $\mathrm{ha}^{-1}$ is beneficial for improving mungbean grain yield in Semi-arid region.

Key words: Grain yield; Biological yield; Biochar (BC); Mungbean

\section{Introduction}

Mungbean (Vigna radiate) is also known as green gram or golden gram, a member of the Fabaceae family. In Pakistan it is cultivated within area of 137.4 thousand hectare, production of 76.2 thousand tones and with an average yield of $555 \mathrm{~kg} \mathrm{ha}^{-1}$. While in Khyber Pakhtunkhwa it is cultivated on an area of 8.5 thousand hectare with an annual production of 5.1 thousand tones, having an average yield of $600 \mathrm{~kg} \mathrm{ha}^{-1}$ [1]. Mungbean is an important pulse crop in many Asian countries including Pakistan where the diet is mostly based on cereal. If the mungbean seed does not meet the normal sprouting, so it can be used as a livestock food with about 1.5 ton of mungbean being the same as to 1.0 tons of soybean meal for protein content [2]. As a leguminous crop it improves soil fertility. The average yield of mungbean is very low (763.50 kg ha $\mathrm{kg}^{-1}$ as compared to the potential yield i.e. 2 to 4 ton $\mathrm{ha}^{-1}$, which needs the focus of the crop experts [3]. Proper fertilizer management will not only enhance the productivity of mungbean but 
also improve the soil fertility. Biochar is a fine grain charcoal high inorganic carbon and largely resistant to decomposition. It is created by pyrolysis of biomass such as plant and waste feedstock's. Due to its porous quality and large surface area it reduces leaching of nutrients [4]. Biochar mitigates environmental pollution. The nutrient uptake was greatly improved with increasing biochar application in combination with other commercial fertilizer [5]. Addition of biochar enhances the efficacy of $\mathrm{N}$ fertilizers and hence augmented the growth and yield [6]. Biochar addition to mungbean crop made it capable to compensate for low $\mathrm{N}$ availability due to improved biological N2 fixation [7]. Keeping in view the importance of biochar, the present study was initiated to determine the best level of biochar for improving yield and yield components of mungbean in agro ecological condition of Peshawar.

\section{Materials and methods}

A pot experiment entitled "Impact of biochar on mungbean yield and yield components" was conducted at the Agronomy Research Farm, The University of Agriculture Peshawar, Pakistan during summer 2013. The experiment was consisted of different levels of biochar 0,25 , 50,75 and 100 ton $\mathrm{ha}^{-1}$ respectively. The NM 92 variety of mungbean was sown on $19^{\text {th }}$ March, 2013 and harvested on $20^{\text {th }}$ June, 2013. The experiment was conducted in completely randomized design with four repeats. Fifteen (15) seeds were sown in each pot with a total of four pots per treatment and irrigation was given on daily basis till emergence. After the emergence, the weak plants were removed and left 5 healthy plants in each pot. These 5 plants pot $^{-1}$ were used for data collection. Data was recorded on days to emergence, days to flowering, days to maturity, pods plant $^{-1}$, pods length, grain pod $^{-1}$, hundred seeds weight, biological yield, grain yield and harvest index. Days to emergence data was obtained when visually $75 \%$ of the plants were emerged in each pot from the date of sowing. Days to flowering was conducted by counting the number of days until the $75 \%$ of flower initiate from the date of sowing in each pot. Days to maturity was determined by counting the number of days until the $75 \%$ of pods become fully matured or turn brown or black in color from the date of sowing in each pot. Pods per plant data was recorded by counting the pods of all plants from each pot continuously till harvesting. Data on pods length of mungbean was obtained by measuring the length of five randomly selected pods in each pot and then mean was calculated. Grain $\operatorname{pod}^{-1}$ data was determined by counting the seeds in 10 pods, randomly selected from each pot. Data was obtained by counting and weighing 100 grains selected from grain lot of each pot. The data on biological yield was recorded by harvesting all plants in each pot and was kept in open area for sun drying. It was then weighed with scale. Grain yield pot ${ }^{-1}$ data were determined by taking weight of whole seeds obtained from each pot after harvesting. Harvest index data was obtained by dividing grain yield on biological yield and multiplied with 100 .

Harvest Index $=$ Grain yield $\times 100$

Biological yield

Data was analyzed according to methods described by Steel and [8], and means between the treatments were compared by least significant difference $(\mathrm{P} \leq 0.05)$.

\section{Results and discussions}

\section{Days to emergence}

Data regarding days to emergence of mungbean presented in Fig. 1 shows that biochar had no significant effect on days to emergence. Similarly the different levels of biochar remain non-significant. It may be 
due to genetic factor which cannot be changed by external factors.

\section{Days to flowering}

Data concerning days to flowering of mungbean are presented in Fig. 2 shows that biochar levels had significantly affected days to flowering. The maximum days (50) were taken by control and minimum (36) days with $\mathrm{BC} 25$ tons $\mathrm{ha}^{-1}$. The early flowering observed with BC 25 tons ha ${ }^{-1}$ but with increase in biochar to 50 tons $\mathrm{ha}^{-1}$ the days to flowering delayed. The 100 tons $\mathrm{ha}^{-1}$ $\mathrm{BC}$ took 47 days to produce flower. It can be concluded from these results that by increasing the level of $\mathrm{BC}$ delay flowering. The results are inclining with the finding of [9] that biochar delays flowering. The other possible reason might be that $\mathrm{BC}$ interferes with soil carbon content which leads to change in $\mathrm{C}: \mathrm{N}$ ration and microbial population. This increase in $\mathrm{C}: \mathrm{N}$ ratio enhances early flowering [10].

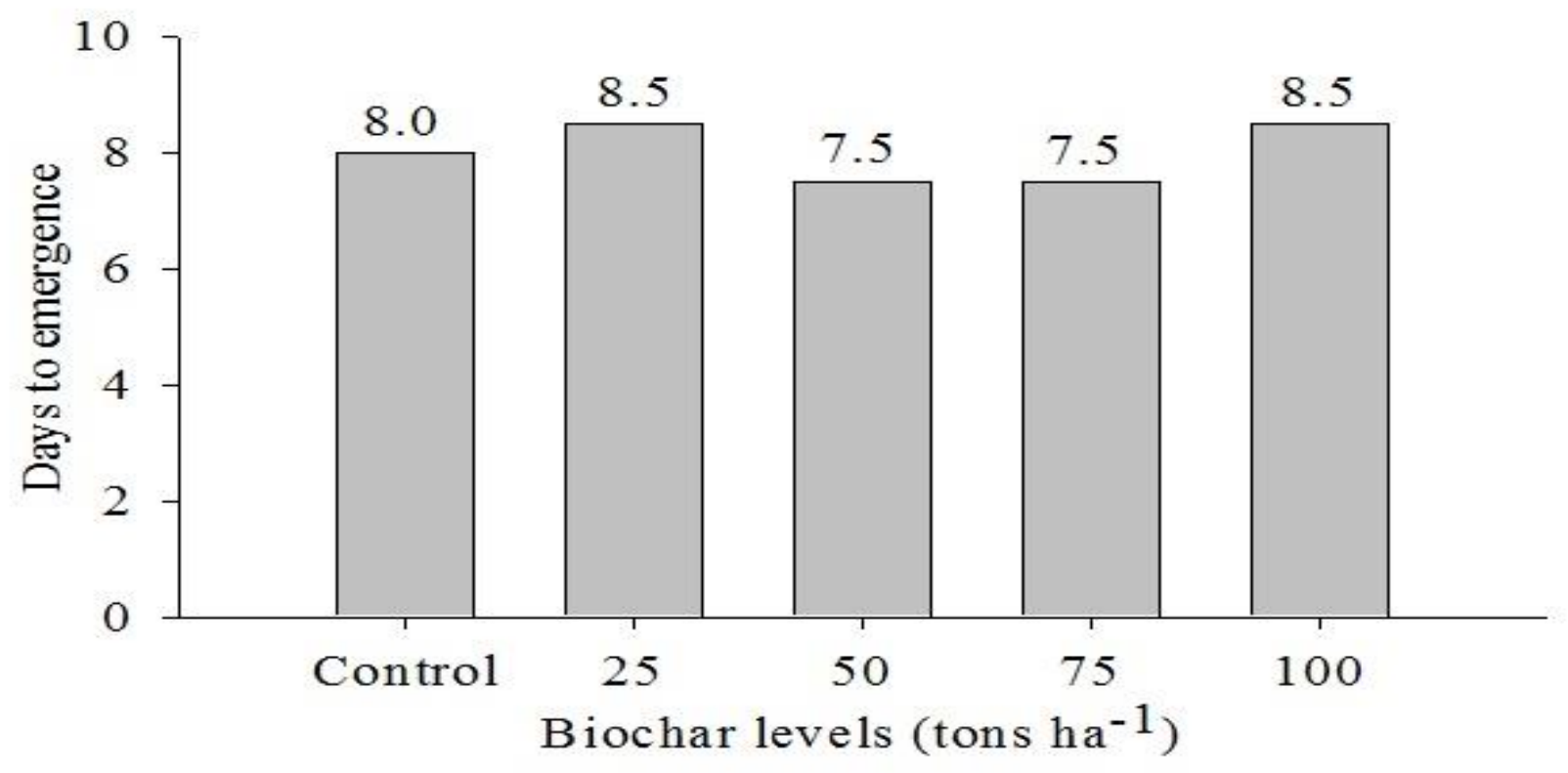

Figure1. Days to emergence of mungbean as affected by different level of biochar

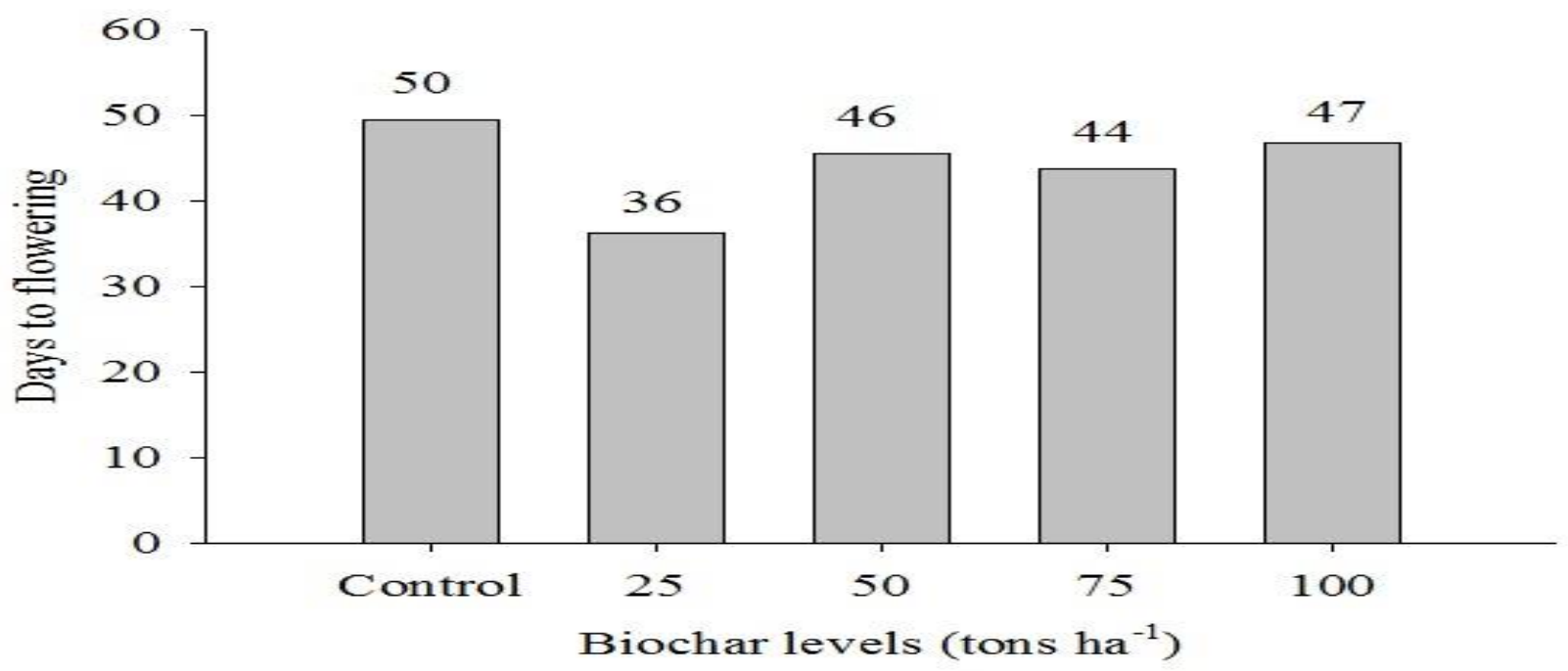

Figure 2. Days to flowering as affected by different level of biochar 


\section{Days to maturity}

Data about days to maturity of mungbean presented in Fig. 3 shows that the effect of biochar on days to maturity was significant. Among the treatments the maximum days (89) were taken by control and the minimum (81) days with BC 25 tons ha ${ }^{-1}$. The early maturity was observed when $\mathrm{BC}$ applied at the rate of 25 tons ha ${ }^{-1}$. Delayed maturity was recorded where $\mathrm{BC}$ was applied at the rate of 50 tons $\mathrm{ha}^{-1}$ delayed maturity and the 100 tons $\mathrm{ha}^{-1}$ took 83 days to reach maturity. So it can be concluded from these results that decreasing in $\mathrm{BC}$ levels enhance maturity while increase in BC levels resulted in delay maturity. Likewise, [11] biochar application delayed maturity in crops. The possible reason for this might be the availability of timely and balanced nutrients as well as conducive soil conditions which help the plant to grow vigorously and thus delayed the maturity [6].

\section{Pods plant ${ }^{-1}$}

It is evident from the data presented in Fig. 4 that biochar levels had significantly affected the number of pods. Data indicated that higher numbers of pods (22) was observed with BC 25 tons $\mathrm{ha}^{-1}$ and lower in control (12). At 50 and 75 tons $\mathrm{ha}^{-1}$ the numbers of pods were 16 and 15 respectively but at 100 tons ha $^{-1}$ it again increased (21). Pods per plant are important yield determining factor. Low biochar resulted in higher pods; it might be due to the $\mathrm{BC}$ application which increased the $\mathrm{C}: \mathrm{N}$ ratio and reproductive growth in mungbean. These results are confirmed with [2] who reported that number of pods per plant increase with biochar. At 50 and 75 tons $\mathrm{ha}^{-1} \mathrm{BC}$ application the number of pods decreased. This decrease might be the high $\mathrm{C}: \mathrm{N}$ ratios of $\mathrm{BC}$ when added to the soil results in immobilization of ammonium and nitrogen which leads to decreased in number of pods. But at 100 tons $\mathrm{ha}^{-1}$ of $\mathrm{BC}$ application again increased the number of pods plant ${ }^{-1}$, it would be due to change in microbial population, as soil microbes use carbon as a source of energy. If there is too much carbon, decomposition slows down and some organisms die, thus carbon is available to plant while the remaining carbon burns.

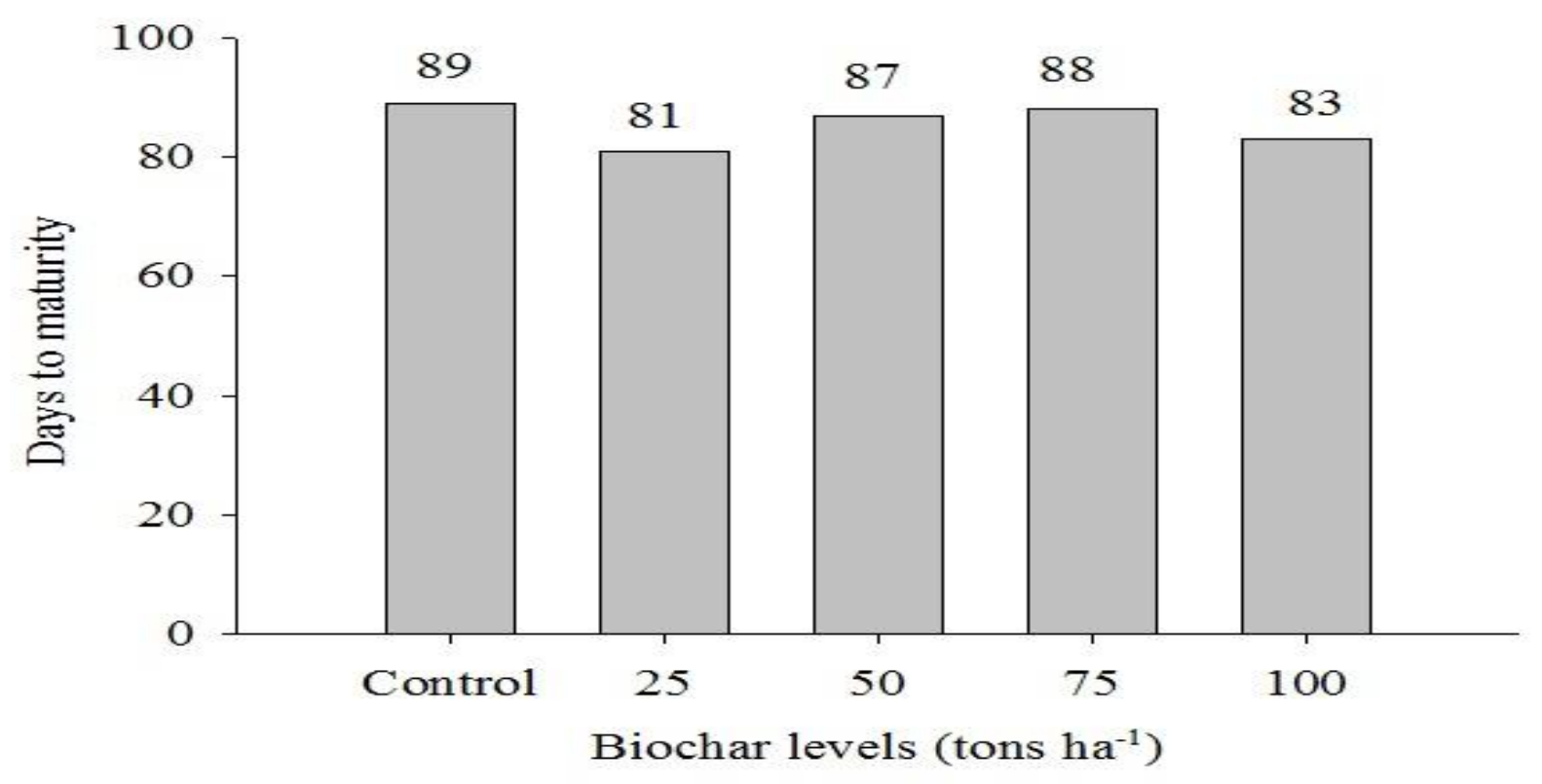

Figure 3. Days to maturity as affected by different level of biochar 


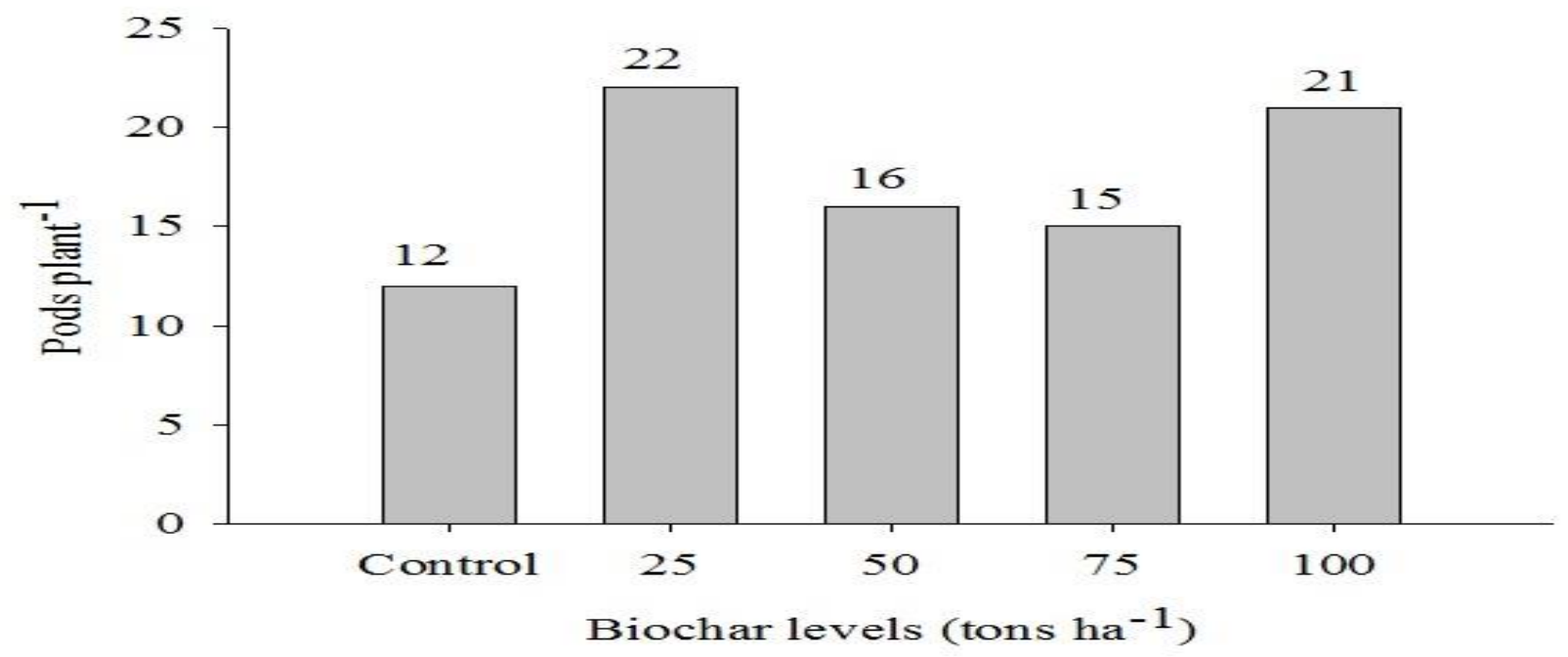

Figure 4. Pods plant ${ }^{-1}$ as affected by different level of biochar

\section{Pods length (cm)}

Data associated with pods length of mungbean are presented in Fig. 5 showed that pods length was highly significant. Longer pods $(9 \mathrm{~cm})$ were determined with 25 and 100 tons ha ${ }^{-1}$ while shorter $(6 \mathrm{~cm})$ in control pots. Pods length was increased with BC application. The probable reason might be that biochar had provided maximum nutrients which increased pods length. The same findings were observed by [12] who stated that biochar significantly influenced pods length.

\section{Grains pods ${ }^{-1}$}

Data regarding numbers of grains pod $^{-1}$ are presented in Fig. 6 shows that there was a significant effect of biochar on number of grains $\operatorname{pod}^{-1}$. Higher numbers of grains (11) were obtained with application of 100 tons $\mathrm{ha}^{-1} \mathrm{BC}$ and lower (7) was obtained from control. As grain per plant are the one of the main factor responsible for yield. Higher biochar level tend towards the higher numbers of grains, it shows that biochar increased the reproductive efficiency of mungbean. Same results are found by $[13$ \& 2] they determined that biochar application has enhanced the positive effect on number of seed per pod in mungbean. The possible reason might be that soil $\mathrm{C}$ : $\mathrm{N}$ ratios are lower during hot seasons and $\mathrm{BC}$ increases $\mathrm{C}$ : $\mathrm{N}$ ratio of soil which tends to increase in grain $\operatorname{pod}^{-1}$.

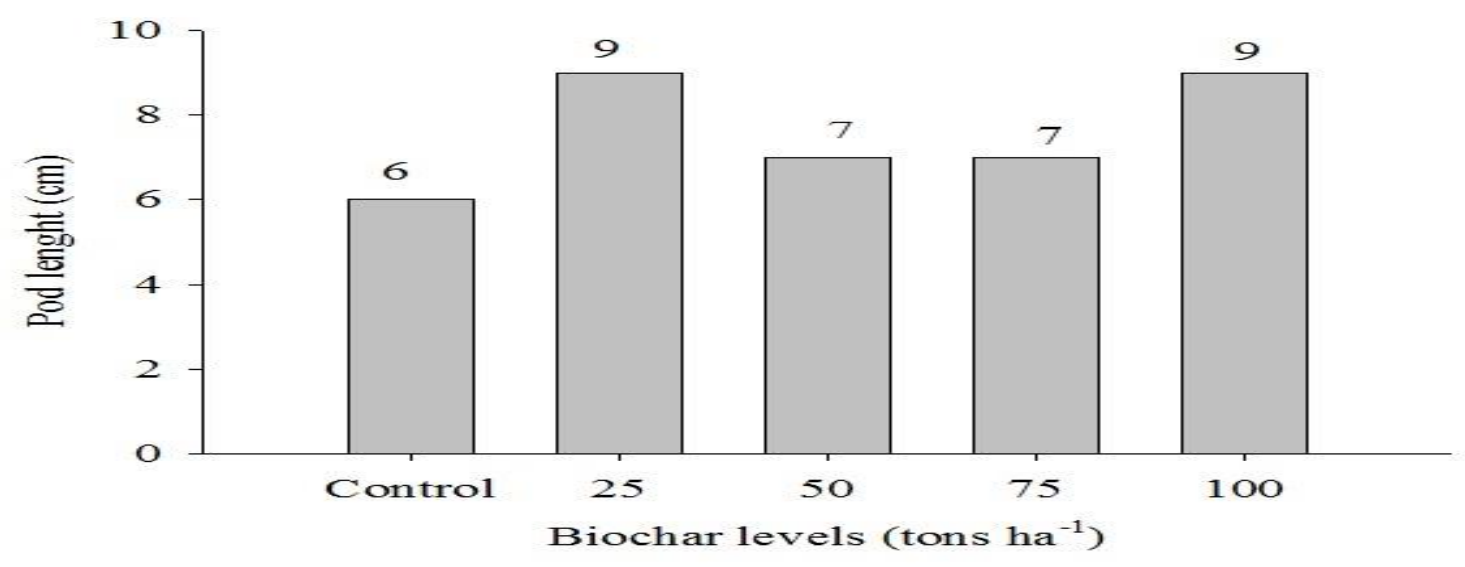

Figure 5. Pods length as affected by different level of biochar 


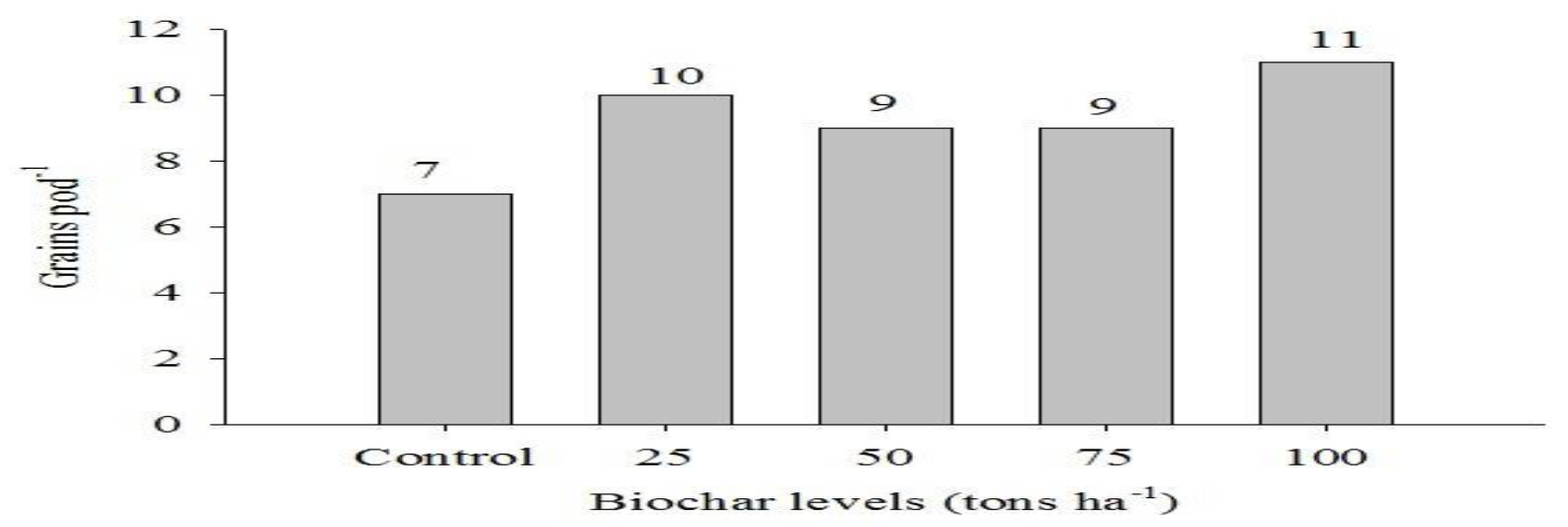

Figure 6. Grain pods ${ }^{-1}$ as affected by different level of biochar

\section{Hundred grain weight (g)}

Data regarding hundred grain weight presented in Fig.7 showed a significant effect of biochar on mungbean. The maximum hundred grain weight $(6.8 \mathrm{~g})$ was conducted with 100 tons $\mathrm{ha}^{-1}$ and minimum $(3.6 \mathrm{~g})$ with control. Again increasing the rate of biochar resulted in greater grain size, the possible reason for this may be that biochar provide the necessary minerals which improved content in grains as a result grain size is increased. Our results are in line with [6] who found that hundred grain weight increases with the application of BC.

\section{Biological yield $\left(\mathrm{g} \mathrm{pot}^{-1}\right)$}

Data regarding biological yield indicates a significant effect of biochar on mungbean presented in Fig. 8. Biological yield was lowest $\left(22.0 \mathrm{~g} \mathrm{pot}^{-1}\right)$ in control treatment while highest $\left(28.3 \mathrm{~g} \mathrm{pot}^{-1}\right)$ with 25 tons $\mathrm{ha}^{-1}$. The 100 tons $\mathrm{ha}^{-1}$ produced $(25.8 \mathrm{~g}$ pot $^{-1}$ ) while 50 and 75 ton $\mathrm{ha}^{-1}$ (19.3 and $16.8 \mathrm{~g} \mathrm{pot}^{-1}$ respectively). The possible reason might be that biochar increases plant growth in slightly acidic soil which is good for mungbean growth, thus biochar enhances vegetative growth and result in higher biological yield. These results are in agreement of [12] who also found that biological yield increases with biochar application in slightly acidic soil. The increase in biochar level decrease biological yield might be due to changes in $\mathrm{C}$ : $\mathrm{N}$ ration and decreased nitrifying bacteria

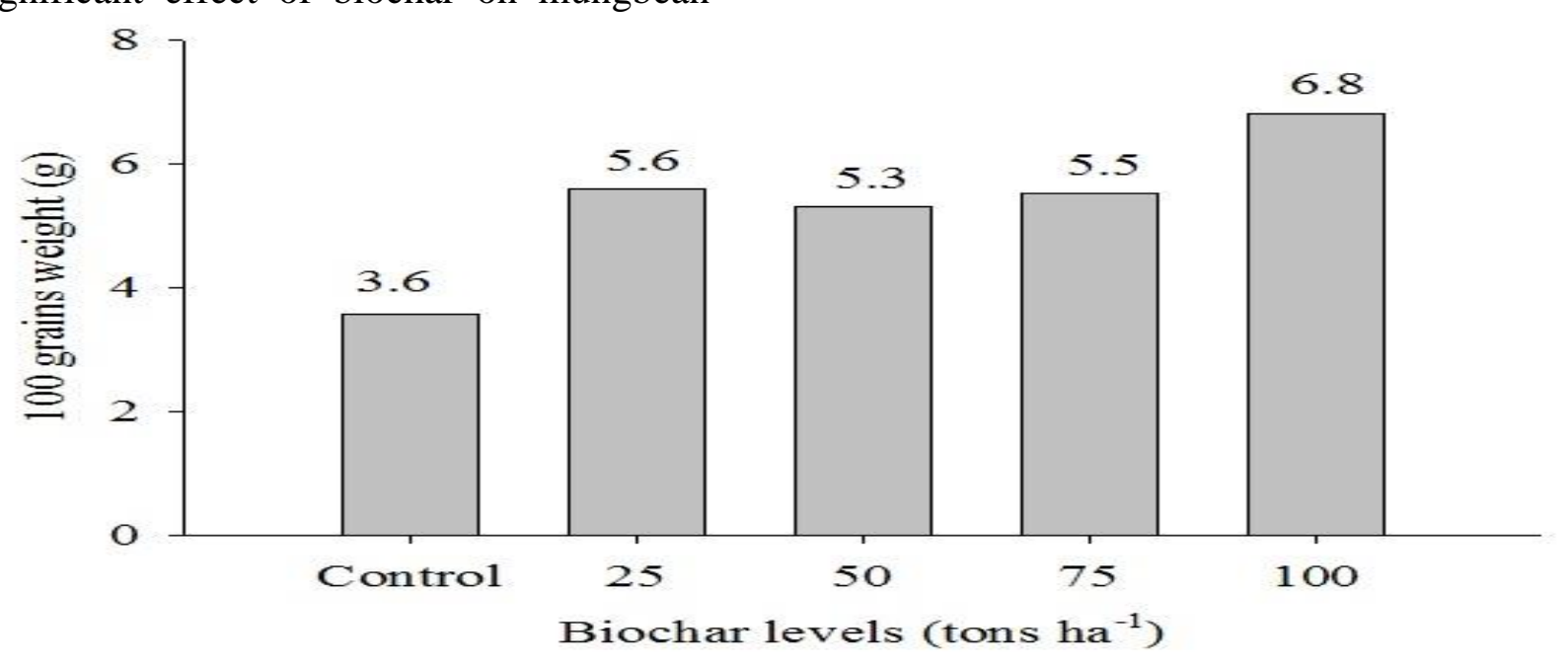

Figure 7. Hundred grain weight as affected by different level of biochar 


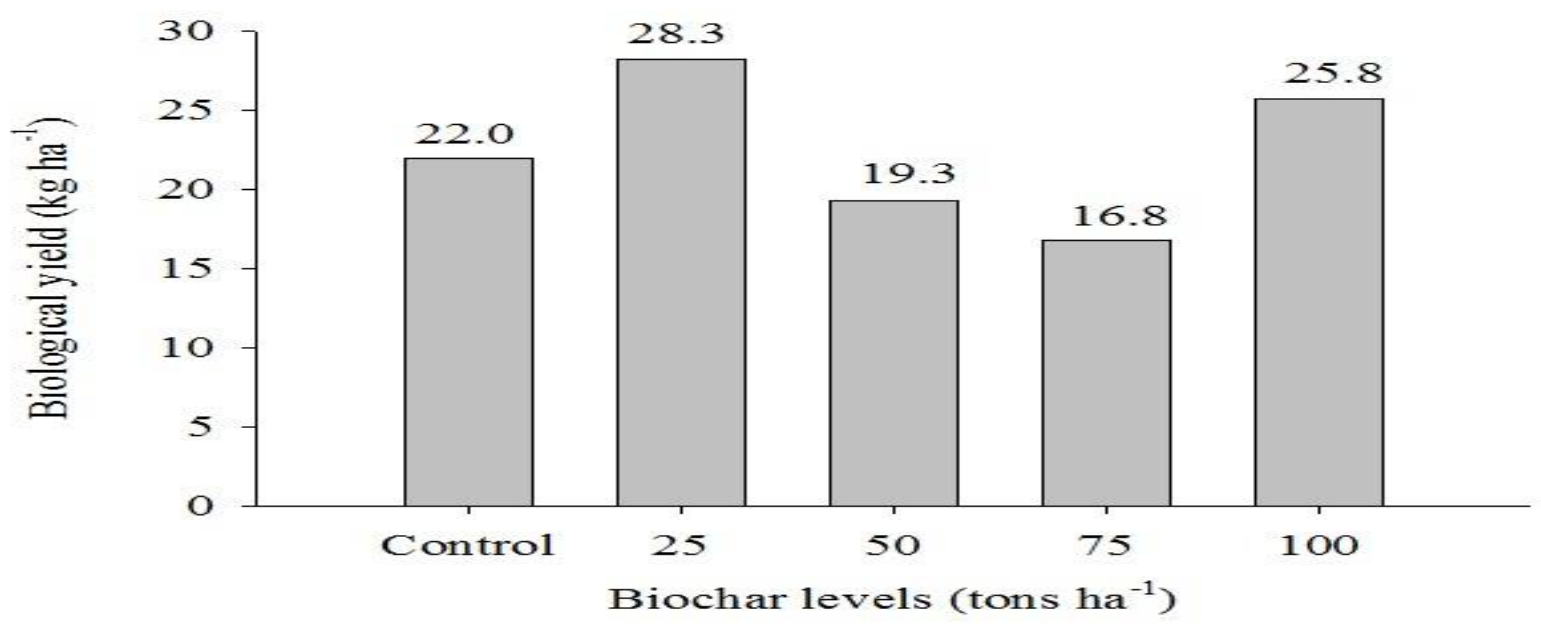

Figure 8. Biological yield as affected by different level of biochar

\section{Grain yield ( g pot $^{-1}$ )}

The grain yield data presented in Fig. 9 indicates that biochar shows significant effect on grain yield of mungbean. According to the data observed it is determined that the highest grain yield (4.2 $\mathrm{g} \mathrm{pot}^{-1}$ ) was obtain with 25 tons ha ${ }^{-1} \mathrm{BC}$ while lowest grain yield $\left(2.7 \mathrm{~g} \mathrm{pot}^{-1}\right)$ was obtain with addition of 75 tons BC ha ${ }^{-1}$. Increased in grain yield is attributed to increase in yield components. Grain yield increases with the increase in BC level. These results are in line with $[14,13]$ who stated that $\mathrm{BC}$ applied at 100 tons $\mathrm{ha}^{-1}$ increased grain yield. The possible reason might be that $\mathrm{BC}$ enhanced the reproductive efficiency of mungbean. As mungbean being a leguminous crop fix atmospheric nitrogen and $\mathrm{BC}$ enhanced the nitrogen amount thus lead to greater grain yield. But [4] stated that grain yield is not stable, depends on a cultivar and environment greatly influenced grain yield.

\section{Harvest index (\%)}

Data pertaining harvest index of mungbean are presented in Fig. 10 shows a significant effect of biochar. Highest harvest index $(16.2 \%)$ was observed when BC was applied at the rate of 75 tons $\mathrm{ha}^{-1}$ where 100 tons $\mathrm{BC}$ resulted in lower $(13.2 \%)$ harvest index. Harvest index is affected by different level of biochar, increasing biochar showed increased in harvest index. These results are similar to findings of $[15,12]$ also reported that biochar stimulate harvest index.

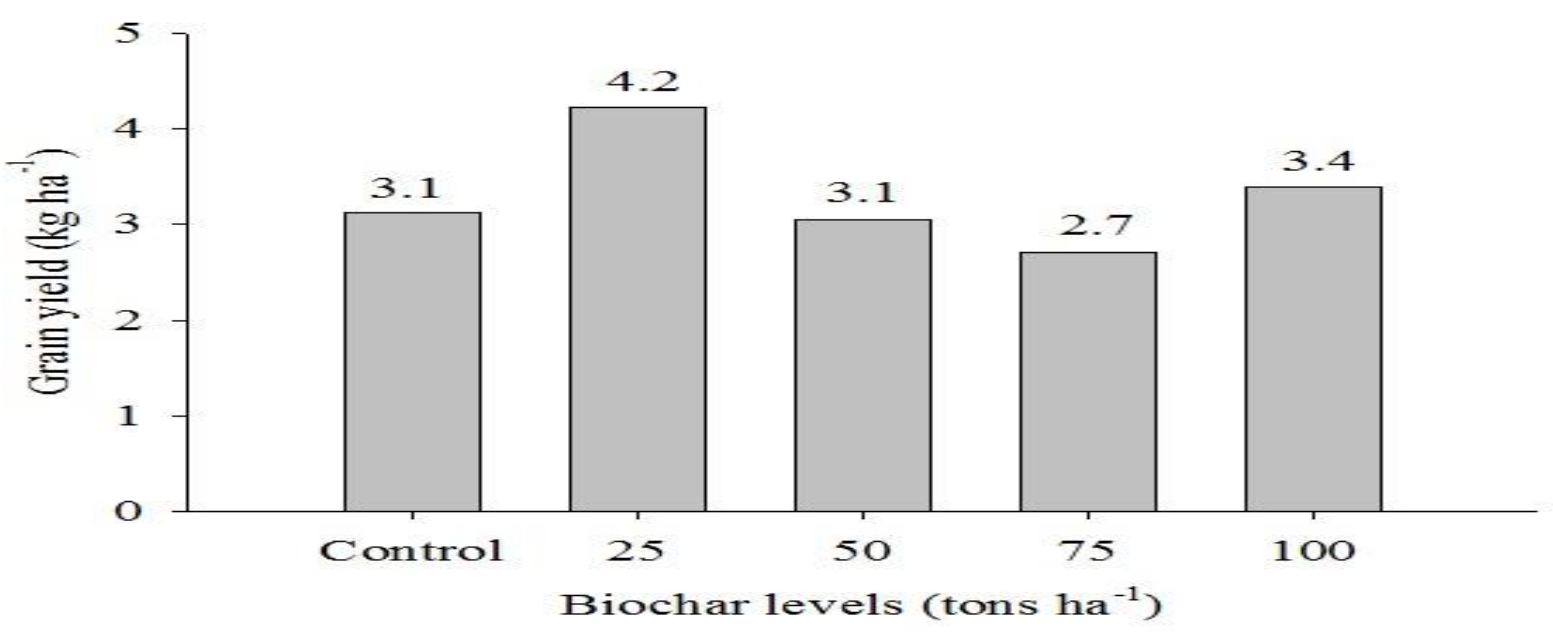

Figure 9. Grain yield as affected by different level of biochar 


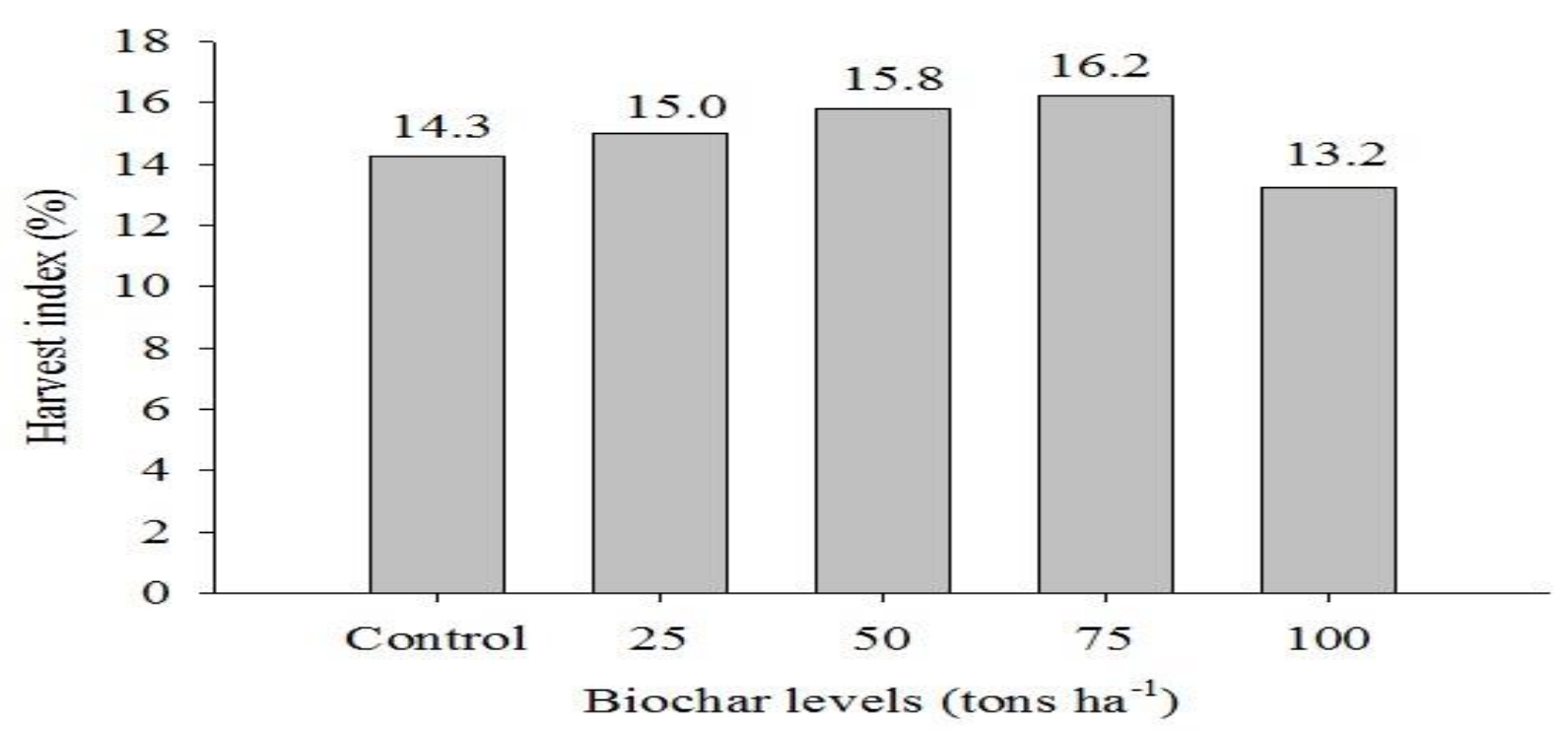

Figure 10. Harvest index as affected by different level of biochar

\section{Conclusion and recommendation}

On the basis of findings obtained in this research study, it is concluded that biochar at the rate of 25 ton $\mathrm{ha}^{-1}$ produced higher biological and grain yield, however its higher rate $\left(100\right.$ ton $\left.\mathrm{ha}^{-1}\right)$ produced at par grain yield and hence lower rate of 25 ton $\mathrm{ha}^{-1}$ is recommended for higher yield of mungbean in agro ecological condition of Peshawar.

\section{Authors' contributions}

Conceived and designed the experiments: MZ Afridi, F Munsif \& M Arif, Performed the experiments: A Rab, SU Haq, S Zahid $\&$ M Asim, Analyzed the data: A Rab, MR Khan \& M Arif, Contributed reagents/materials/analysis tools: A Rab, M Asim \& MR Khan, Wrote the paper: A Rab, SU Haq, S Zahid \& MR Khan

\section{References}

1. Lehmann J, Silva D, Steiner C, Nehls P, Zech T, \& Glaser W (2003). Nutrient availability and leaching in an archaeological Anthrosol and a Ferralsol of the Central Amazon basin: fertilizer, manure and charcoal amendments. Plant \& Soil 249: 343-357

2. Saxena J, Rana G, \& Pandey M (2013). Impact of addition of biochar along with Bacillus sp on growth and yield of French beans. Scientia Horticulturae 162: 351-356

3. Ramakrishna A, Gowda, \& Johansen C (2000). Management factors affecting legumes production in the Indo Gangetic Plain. In: Legumes in rice and wheat cropping systems of the IndoGangetic Plain-constraints and opportunities. 156-165

4. Cornelissen G, Martinsen V, Shitumbanuma V, Alling V, Gijs D, Rutherford B, Sparrevik WDM, Hale SE, Obia A, \& Mulder J(2013). Biochar effect on Maize yield and soil characteristics in five conservation farming sites in Zambia. Agron 3: 256274

5. Major J, Rondon M, Molina D, Riha SJ \& Lehmann J (2010). Maize yield and nutrition during 4 years after biochar application to a Colombian savanna oxisol. Plant Soil 333:117-128

6. Arif M, Ali A, Umair M, Munsif F, Inamullah KA, Saleem M, \& Ayub G (2012). Effect of biochar FYM and mineral nitrogen alone and in combination on yield and yield 
components of maize. Sarhad J Agric 28(2):191-195

7. Zwieten LV, Kimber ES, Downie A, Morris S, Petty S, Rust J,\& Chan KY (2010). A glasshouse study on the interaction of low mineral ash biochar with nitrogen in a sandy soil. Soil Research 48(7): 569-576.

8. Steel RGD \& Torrie JH (1980). Principles and procedures of statistics. $2^{\text {nd }}$ ed. McGraw Hill. New York.

9. Yuan JH \& Xu R (2012). Effects of biochar generated from crop residues on chemical properties of acid soils from tropical and subtropical China. Soil Research 50 (7): 570-578.

10. Galinato SP, Yoder JK \& Granatstein D (2011). The economic value of biochar in crop production and carbon sequestration. Energy Policy 39(10): 6344-6350

11. MINFAL (2012). Agricultural statistics of Pakistan. Ministry of food Agric and livest Govt. Pakistan, Islamabad.

12. Carter S, Shackley S, Sohi S, Suy T B $\&$ Haefele S (2013). The Impact of
Biochar Application on Soil Properties and Plant Growth of Pot Grown Lettuce (Lactuca sativa) and Cabbage (Brassica chinensis). Agron 3: 404-418

13. Solaiman MZ, Blackwell P, Abbott LK \& Storer P (2010). Direct and residual effect of biochar application on mycorrhizal root colonisation, growth and nutrition of wheat. Soil Research 48(7): 546-554

14. Antonio JA, Salazar P, Barrón V, Torrent J, María Del, Carmen, Campillo, Gallardo A, \& Villar R (2013). Enhanced wheat yield by biochar addition under different mineral fertilization levels. Agron Sustain Dev 33:475-484

15. Wang J, Pan X, Liu Y, Zhang X, \& Xiong Z (2012). Effects of biochar amendment in two soils on greenhouse gas emissions and crop production. Plant Soil DOI 10.1007/s11104-0121250-3. 